\title{
Temporal and spatial variations in the distribution of macroalgal communities along the Yantai coast, China*
}

\author{
HAN Qiuying (韩秋影) ${ }^{* *}$, LIU Dongyan (刘东艳) \\ Key Laboratory of Coastal Zone Environmental Processes, CAS; Shandong Provincial Key Laboratory of Coastal Zone \\ Environmental Processes; CAS Experimental Station of Integrated Coastal Environment in Muping; Yantai Institute of Coastal \\ Zone Research, Chinese Academy of Sciences, Yantai 264003, China
}

Received Aug. 19, 2013; accepted in principle Oct. 10, 2013; accepted for publication Dec. 5, 2013

(c) Chinese Society for Oceanology and Limnology, Science Press, and Springer-Verlag Berlin Heidelberg 2014

\begin{abstract}
To explore the impact of environmental variables on macroalgal communities, their temporal and spatial distributions were examined along the Yantai coast, China between April 2010 and March 2011. Macroalgae sampling was conducted monthly at four sites along the coast: Jiahe River estuary, Zhifu Island, Fisherman's Wharf, and Yangma Island. The species composition and abundance, and their relationship with environmental variables were assessed. Along the Yantai coast, 35 macroalgae species were identified, including 24 Rhodophyta spp., 7 Chlorophyta, and 4 Phaeophyta spp. Highest species numbers were recorded in the summer at all sampling sites, except in the Jiahe River estuary. Macroalgae biomass was the greatest in the summer. Year-round, the highest species number and dry biomass recorded at Fisherman's Wharf and Yangma Island was attributed to the substrate type. In summer, Ulva pertusa Kjellman was the dominant species identified along the Yantai coast, which indicates a risk of macroalgae blooms. Our results show that seawater temperature and nutrients appear to significantly affect the temporal and spatial patterns of macroalgal abundance along the Yantai coast. The effects of environmental variables on the macroalgae on the Yantai coast need further study.
\end{abstract}

Keyword: macroalgae; temporal; spatial; intertidal; nutrient; Yantai coast; China

\section{INTRODUCTION}

Benthic macrophytes are major contributors to total primary productivity of temperate estuaries (Correll, 1978). Macroalgae has a key role in biogeochemical cycles and acts as a food source and habitat for grazing marine animals and small estuarine invertebrates (Flindt et al., 1999; Melville, 2005). Macroalgae are exposed to steep environmental gradients, including immersion and submersion during tidal cycles, and fluctuating temperature, salinity, light and nutrient levels (Fitzgerald, 1978; Arnold and Murray, 1980; Gordon et al., 1980; Shellem and Josselyn, 1982; Pregnall and Rudy, 1985). Globally, increased human activity has resulted in coastal eutrophication, and thus excessive growth of fast-growing macroalgae (Pregnall and Rudy, 1985; Kinney and Roman, 1998). Subsequently, intertidal ecosystems have been degraded throughout temperate and tropical regions (Burkholder et al., 2007).
Increasing anthropogenic-induced nutrient input can lead to a decrease in the biomass of macroalgae species sensitive to nutrients. It can also cause an increase in the biomass of macroalgae that thrive in high-nutrient environments. Subsequently, macroalgal blooms will occur, and the species composition of macroalgal communities will be altered-for example, a shift in dominance from perennial to annual species of macroalgae (Peckol and Rivers, 1995; Díez et al., 1999; Lapointe and Bedford, 2007). In some regions of the world, green macroalgae is more widespread than red and brown macroalgae owing to high nutrient levels; these regions include

\footnotetext{
* Supported by the National Natural Science Foundation of China (No. 41106099), the Yantai Science and Technology Bureau (No. 2011061), CAS Scientific Project of Innovation and Interdisciplinary, the Key Research Program of Chinese Academy of Sciences (No. KZZD-EW-14), and the Natural Science Foundation of Shandong Province (No. ZR2009EQ006) ** Corresponding author: qyhan@yic.ac.cn
} 

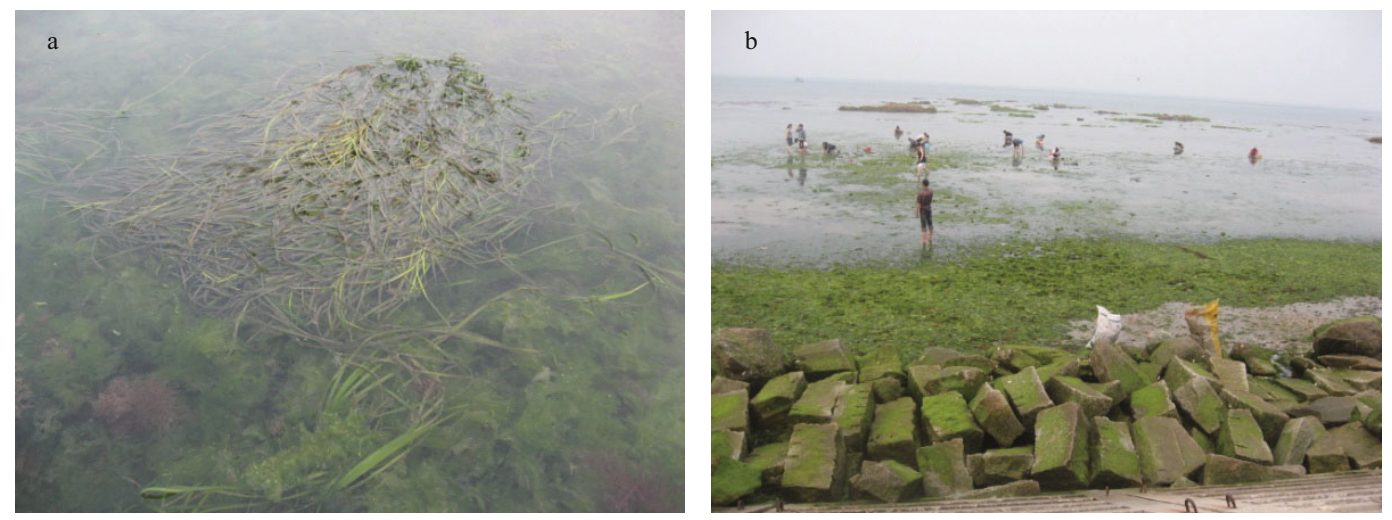

Fig.1 Ulva pertusa Kjellman bloom in Fisherman's Wharf, Yantai coast in the summer, 2009

Waquoit Bay (in Massachusetts, USA) and the European Atlantic coast (Peckol and Rivers, 1995; Bermejo et al., 2012). For example, Cladophora sp. is the dominant macroalgae ( $>0.5 \mathrm{~m}$ thick) in Waquoit Bay under eutrophication conditions (Peckol and Rivers, 1995). The decreasing oxygen concentration caused by abundant algae raises the photosynthetic energy requirements of macroalgae and thus further constricts macroalgal growth (Diaz and Rosenberg, 1995; Niggl et al., 2010). Macroalgae mats can also reduce ecosystem stability by releasing nutrients into the environment (McGlathery, 2001).

Yantai, located in the north of China by the north Yellow Sea, is one of the fastest developing areas in China. Since the 1980s, Yantai coastal waters have received increasing amounts of nutrients from marine aquaculture, wastewater, and harbor pollution (Wang et al., 2012). Approximately 150 tons of phosphorus and 1910 tons of nitrogen are released into the coastal area near Yantai from sewage every year (Liu et al., 2006). Spatial distribution patterns of benthic macroalgae in the Yantai intertidal zones were studied by Zhuang et al. (2001), with 21 species of red alga identified in Zhifu Island, Jingouzhai, Moon Bay, and Yangma Island. In the Moon Bay, the macroalgae species richness varied over all four seasons, and was higher in spring and autumn than in summer and winter (Zhuang and Chen, 2003). In the intertidal and subtidal zones around Fisherman's Wharf, Ulva pertusa Kjellman macroalgae blooms were observed in the summer (Fig.1). However, it is unknown whether nutrient concentrations or other environmental variables induced the $U$. pertusa bloom. For sustainable management of the region, it is important to understand the causes of macroalgal blooms.

To better understand the macroalgae distribution and potential bloom-inducing environmental variables, macroalgae distribution, abundance, and species composition were monitored along the intertidal zone of the Yantai coast for one year. Environmental variables were also measured, namely nutrient concentration, seawater temperature, salinity, $\mathrm{pH}$ and dissolved oxygen levels.

\section{MATERIAL AND METHOD}

\subsection{Site description and sampling methods}

Four study sites were chosen along the Yantai coast, which represented different intertidal habitats (rock, pebble and sand) and were affected by different human activities. Sites were: Jiahe River estuary (A) $\left(37^{\circ} 34^{\prime} 39.3^{\prime \prime}-37^{\circ} 34^{\prime} 40.9^{\prime \prime} \mathrm{N}, \quad 121^{\circ} 17^{\prime} 40.9^{\prime \prime}-121^{\circ} 17^{\prime}\right.$ $\left.41.3^{\prime \prime} \mathrm{E}\right)$, Zhifu Island (B) (37 $37^{\prime} 14.6^{\prime \prime}-37^{\circ} 37^{\prime} 18.1^{\prime \prime} \mathrm{N}$, $\left.122^{\circ} 09^{\prime}-122^{\circ} 42^{\prime} \mathrm{E}\right)$, Fisherman's Wharf (C) $\left(37^{\circ} 30^{\prime}\right.$ 08.3"-37 $\left.30^{\prime} 13.2^{\prime \prime} \mathrm{N}, 121^{\circ} 26^{\prime} 42.6^{\prime \prime}-121^{\circ} 26^{\prime} 46.1^{\prime \prime} \mathrm{E}\right)$, and Yangma Island (D) $\left(37^{\circ} 28^{\prime} 37.2^{\prime \prime}-37^{\circ} 28^{\prime} 42.0^{\prime \prime} \mathrm{N}\right.$, $121^{\circ} 38^{\prime} 29.6^{\prime \prime}-121^{\circ} 38^{\prime} 38.9^{\prime \prime} \mathrm{E}$ ) (Fig.2). Monthly sampling was conducted from April 2010 to March 2011. Jiahe is the largest river entering the north Yellow Sea and brings large quantities of fresh water into the sea, particularly in the summer. There is an artificial dam in the Jiahe River estuary $(20 \mathrm{~m} \times 3 \mathrm{~m})$, where the substrate is sand and smooth rock, but there were no macroalgae in the sandy substrate (authors' investigation). Samples were only collected in AprilOctober in 2010 and March in 2011 because of the high water level and strong wave action. On Zhifu Island, there is a pollutant outfall, where all domestic sewage from the Zhifu district discharges into the sea. At this site, the substrate is smooth rock and the intertidal area is approximately $20 \mathrm{~m} \times 4 \mathrm{~m}$. Fisherman's Wharf is severely affected by human activities, as many people dig and collect the macrofauna at low tide. The nearby Zostera marina bed has been severely degraded in recent years. At Fisherman's Wharf, the intertidal zone $(800 \mathrm{~m} \times$ 


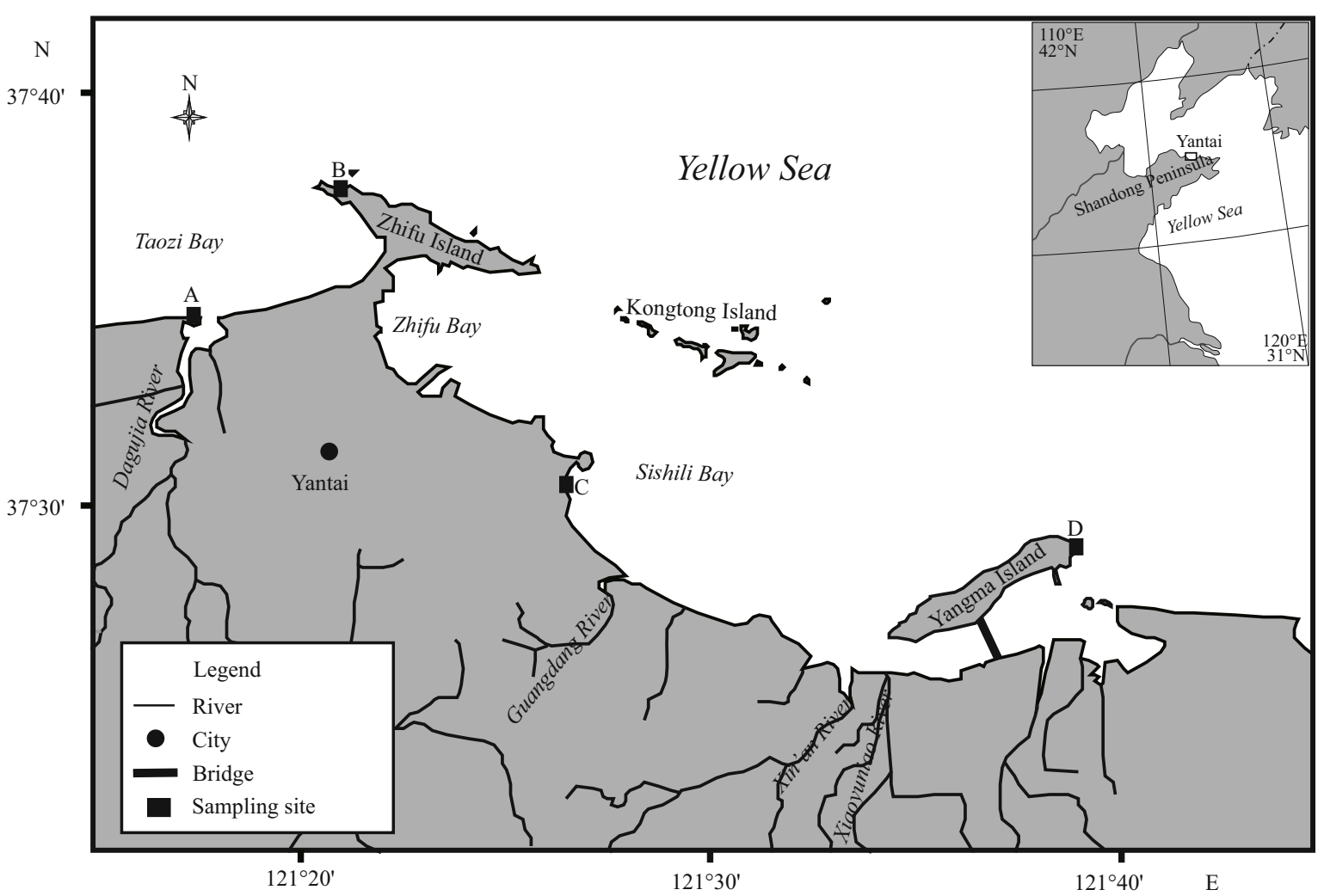

Fig.2 Study areas and sampling site on the Yantai coast, China

A. Jiahe River estuary; B. Zhifu Island; C. Fisherman's Wharf; D. Yangma Island

$365 \mathrm{~m}$ ) along the tidal gradient is larger than at other locations, and the substrate is pebble. Yangma Island, located in the middle of the northern Yellow Sea, is a protected area measuring $80 \mathrm{~m} \times 3 \mathrm{~m}$, with a pebble substrate.

Because of size differences in the intertidal area, sampling techniques varied between sites. At sites A, $B$ and $\mathrm{D}$, three quadrats $(1 \mathrm{~m} \times 1 \mathrm{~m})$ were sampled. In site $\mathrm{C}$, three transects, approximately $120 \mathrm{~m}$ apart, were set up along the tidal gradient. Along each transect, three stations were selected $200 \mathrm{~m}$ apart, and three quadrats $(1 \mathrm{~m} \times 1 \mathrm{~m})$ of macroalgae were sampled at each station. At all study sites, quadrats were haphazardly placed. All macroalgae was collected from the quadrats and put into a refrigeration box in the field, before being transferred to the laboratory. Macroalgal species were then separated and identified to species level where possible, based on the volumes of the Flora Algarum Marinarum Sinicarum and Zeng (2008). The macroalgae was then frozen and dried, and the dry biomass was determined.

\subsection{Environmental parameters}

Environmental parameters, namely seawater temperature, salinity, $\mathrm{pH}$, and dissolved oxygen (DO) were directly measured with a YSI 30 portable meter in the field at each sampling date. Seawater samples were collected near the sampling stations, put into refrigeration boxes in the field, and transferred to the laboratory for nutrient analysis. Samples were filtered through cellulose acetate membranes (Whatman, $0.45 \mu \mathrm{mol} / \mathrm{L}$ ), and nutrient analysis was conducted using a Flow Injection Analysis (AA3, Bran+Luebbe, Norderstedt Germany) system to measure the following parameters: ammonia, nitrite, nitrate, soluble reactive phosphorus (SRP), total nitrogen (TN) and total phosphate (TP). Dissolved inorganic nitrogen (DIN) was calculated as the total of $\mathrm{NH}_{4}^{+}+\mathrm{NO}_{3}^{-}+\mathrm{NO}_{2}^{-}$. Nutrient analysis was executed according to the WOCE Methods Manual (Gordon et al., 1993). Measurement precision was $0.015 \mu \mathrm{mol} / \mathrm{L}$ for $\mathrm{NO}_{3}-\mathrm{N}, 0.003 \mu \mathrm{mol} / \mathrm{L}$ for $\mathrm{NO}_{2}-\mathrm{N}, 0.04 \mu \mathrm{mol} / \mathrm{L}$ for $\mathrm{NH}_{4}-\mathrm{N}, 0.02 \mu \mathrm{mol} / \mathrm{L}$ for SRP.

\subsection{Data analyses}

The dominant species were determined according to the Important Value Index $\left(\mathrm{IV}_{i}\right)$ (Masson and Greig, 1983), where:

$$
\mathrm{IV}_{i}=n_{i} / N \times f_{i}
$$


$n_{i}$ : each macroalgal species biomass; $N$ : total dry biomass of macroalgae; $f_{i}$ : the proportion of each macroalgal species occurring in all quadrats.

The Shannon-Wiener index $\left(H^{\prime}\right)$ (Shannon and Weaver, 1949) was calculated based on the macroalgal taxonomic composition and their biomass.

$$
H^{\prime}=-\sum_{i=}^{s} P_{i} \times \log P_{i}
$$

$s$ : number of macroalgae; $P_{i}$ : the proportion of each macroalgal species in the total dry biomass.

Macroalgal species overlap was evaluated based on Pianka's niche overlap index $\left(O_{i j}, O_{j i}\right)$ (Pianka, 1973), where:

$$
O_{i j}=O_{j i}=\frac{\sum_{k=1}^{N}\left(P_{i k} \times P_{j k}\right)}{\sqrt{\sum_{k=1}^{N} P_{i k}^{2} \times \sum_{k=1}^{N} P_{j k}^{2}}}
$$

$N$ : number of sampling station; $O_{i j}, O_{j i}$ : Pianka's niche overlap index between $i$ species and $j$ species; $P_{i k}$ : the proportion of $i$ macroalgal species in the total dry biomass at $k$ sampling station; $P_{j k}$ : the proportion of $j$ macroalgal species in the total dry biomass at $k$ sampling station.

Potential correlations between macroalgal dry biomass and environmental variables were examined using bivariate correlations (Hong et al., 2003). Multivariate analysis (stepwise) was used to identify the most important environmental variables affecting the dry biomass of macroalgae (Hong et al., 2003). The differences among environmental parameters and macroalgal dry biomass were analyzed using oneway ANOVA and post hoc tests (Hong et al., 2003). All statistical analyses were conducted in SPSS 11.0. Data are presented as means $( \pm \mathrm{SE})$, and a significance level of $5 \%$ was used in all analyses.

\section{RESULT}

\subsection{Temporal and spatial variations of environmental parameters}

3.1.1 Physical and chemical characteristics of the sampling sites

Seawater temperature displayed significant seasonal changes $(F=729.502, P=0.000)$, with the highest temperature in summer (max. in August: $24.77 \pm 1.01{ }^{\circ} \mathrm{C}$ ) and lowest in winter (min. in January: $-0.81 \pm 0.88^{\circ} \mathrm{C}$ ) (Fig. $3 \mathrm{a}$ ).

Salinity was significantly different across seasons $(F=4.488, P=0.000)$. The lowest recorded salinity was $27.87 \pm 6.12$ in August and the highest was
$31.39 \pm 0.54$ in May (Fig.3b). Salinity was the lowest in the summer, especially in August, because of the fresh water input and increased rainfall on the Yantai coast (Fig.3b). In the Jiahe River estuary, the artificial dam keeps the seawater and fresh water from mixing during the dry season, January-June and OctoberDecember.

Monthly $\mathrm{pH}$ was also significantly different across seasons $(F=19.003, P=0.000)$. The lowest value was $7.67 \pm 0.17$ in January and the highest was $8.47 \pm 0.16$ in March (Fig.3c). pH was lower in winter than all other seasons. Conversely, DO was not significantly different across all months $(F=1.61, P=0.1)$. The lowest value was $9.72 \pm 1.29 \mathrm{mg} / \mathrm{L}$ in August and the highest was $17.45 \pm 1.98 \mathrm{mg} / \mathrm{L}$ in February (Fig.3d). Although not significantly different, DO was lower in summer and autumn than in winter and spring, declining from February to September (Fig.3d). The lowest DO recorded was $7.36 \mathrm{mg} / \mathrm{L}$.

Overall, on the Yantai coast, seawater temperature and salinity showed the temperate climatic regime of the region, with a lower $\mathrm{pH}$ in winter and lower $\mathrm{DO}$ in summer.

\subsubsection{Nutrient characteristics at the sampling sites}

Ammonia concentration was not significantly different during the sampling period $(F=0.51$, $P=0.877)$, accounting for $11 \%-68 \%$ of DIN. The lowest value $(4.1 \pm 9.06 \mu \mathrm{mol} / \mathrm{L})$ recorded was in October and the highest $(17.78 \pm 25.99 \mu \mathrm{mol} / \mathrm{L})$ in December (Fig.4a). Nitrate concentrations were not significantly different across months $(F=0.992$, $P=0.481)$. The lowest level $(3.4 \pm 2.45 \mu \mathrm{mol} / \mathrm{L})$ was recorded in March and the highest $(34.62 \pm 63.69 \mu \mathrm{mol} / \mathrm{L})$ in August (Fig.4b). Nitrate levels were higher at Yangma Island than at the other three study sites, for all months except February, March, May and August (Fig.4b).

DIN concentration varied significantly among months $(F=2.251, \quad P=0.014)$. The lowest value $(14.11 \pm 17.75 \mu \mathrm{mol} / \mathrm{L})$ was recorded in March and the highest $(45.62 \pm 66.42 \mu \mathrm{mol} / \mathrm{L})$ in August (Fig.4c). DIN concentration was the lowest in June-July, and showed high values $(>4.5 \mu \mathrm{mol} / \mathrm{L})$ at all study sites, particularly at Zhifu Island.

The SRP was not significantly different among months $\quad(F=1.5, \quad P=0.135)$. The lowest value $(0.057 \pm 0.028 \mu \mathrm{mol} / \mathrm{L})$ was in August and the highest $(0.13 \pm 0.098 \mu \mathrm{mol} / \mathrm{L})$ in December (Fig.4d). The highest SRP was recorded in Fisherman's Wharf, in all months except May (Fig.4d). 

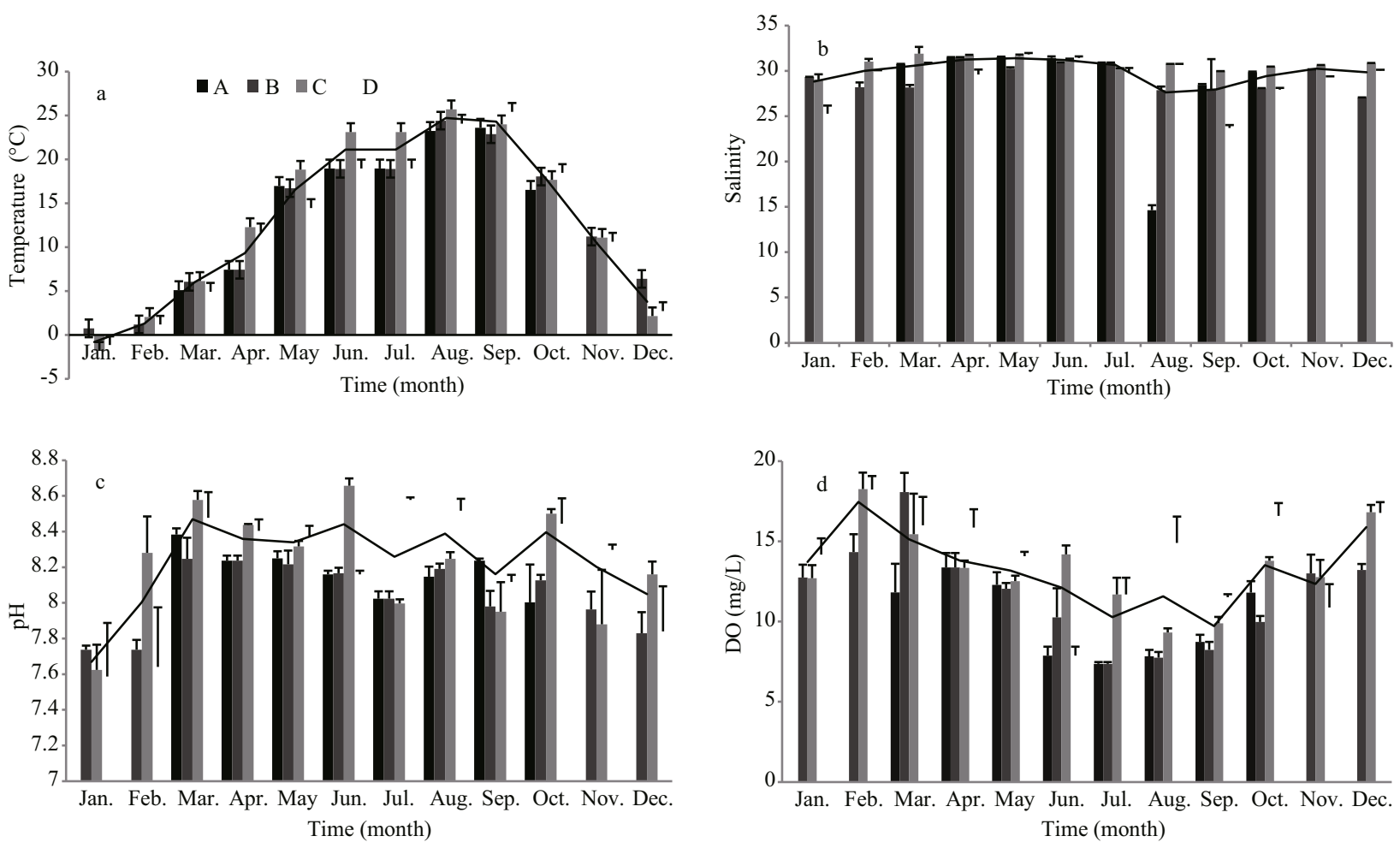

Fig.3 Temporal variations in seawater temperature (a), salinity (b), pH (c), and DO (d) at the study sites (A, B, C, D) from April 2010 to March 2011

Variables are expressed as the mean values of four stations $(n=4)$, and error bars $( \pm \mathrm{SE})$ are given. Lines on the figures are average values of the environmental variable at the four sampling sites.
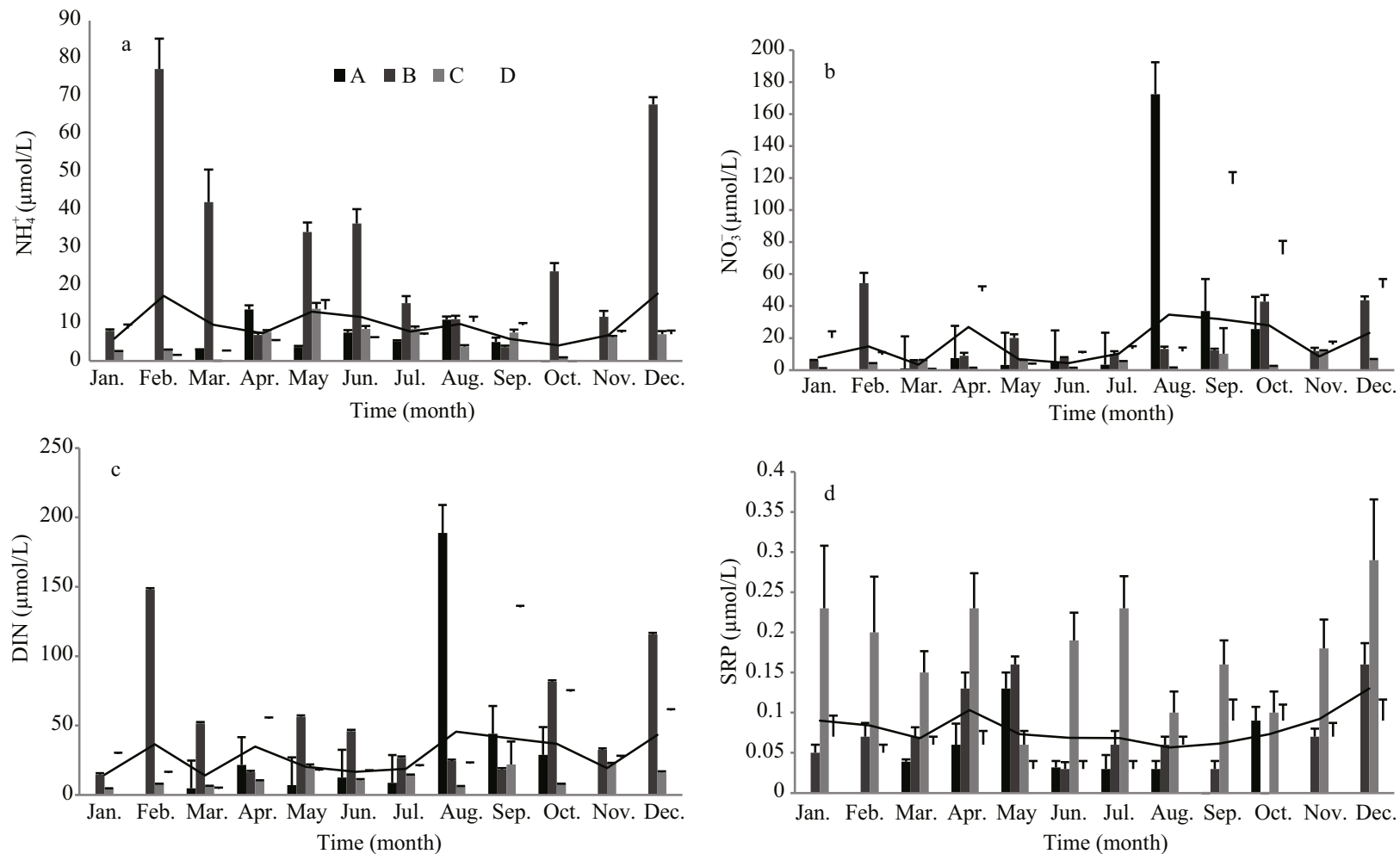

Fig.4 Temporal variations of $\mathrm{NH}_{4}^{+}$(a), $\mathrm{NO}_{3}^{-}$(b), DIN (c) and SRP (d) at the study sites (A, B, C, D) from April 2010 to March 2011 Variables are expressed as the mean values of four stations $(n=4)$, and error bars $( \pm \mathrm{SE})$ are given. Lines on the figures are average values of the environmental variable at the four sampling sites. 
Table 1 Species identified at the Yantai coast

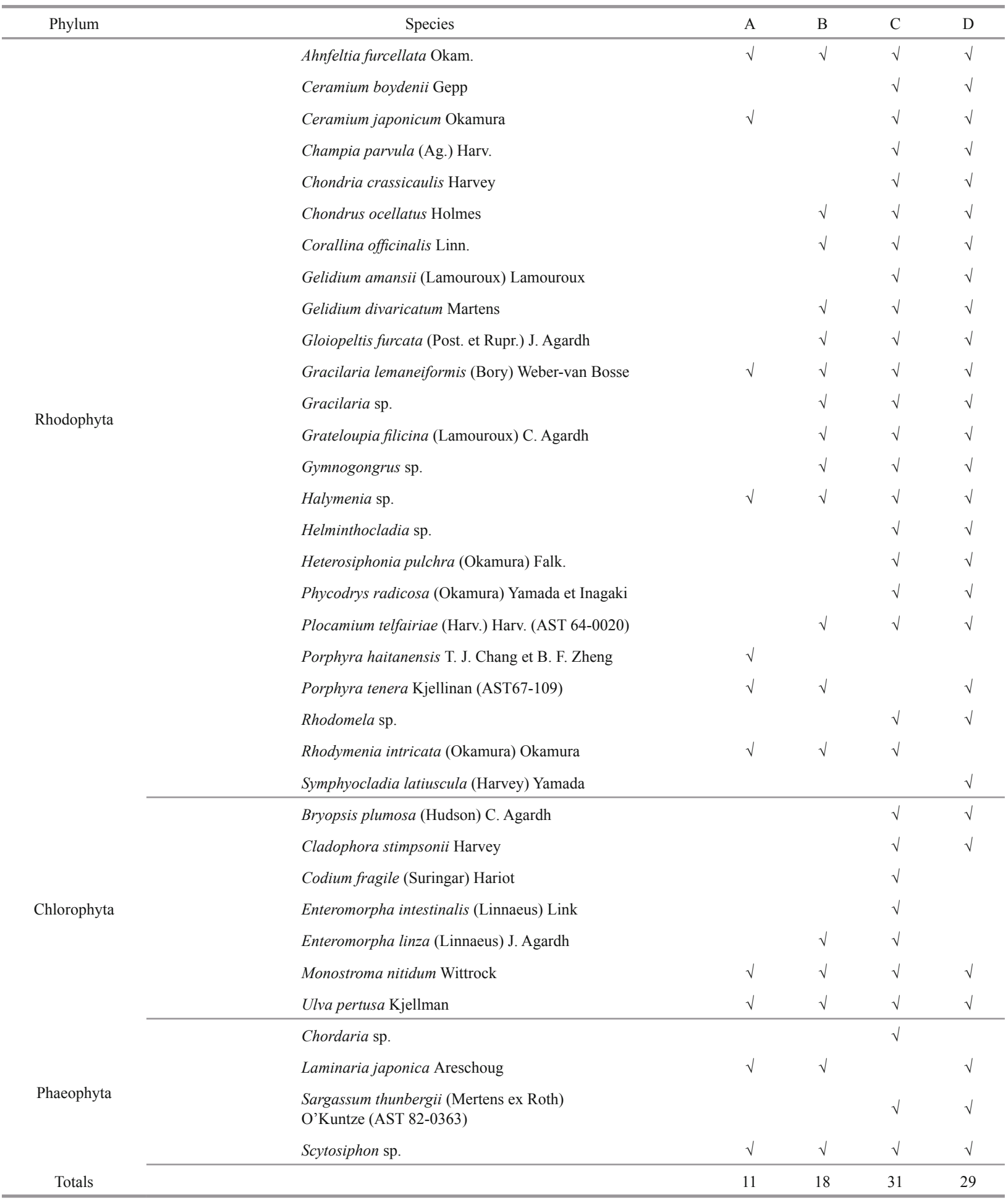

A. Jiahe River estuary; B. Zhifu Island; C. Fisherman's Wharf; D. Yangma Island.

\subsection{Temporal and spatial distribution of macroalgal community}

\subsubsection{Species richness composition}

Along the Yantai coast, 35 macroalgal taxa were identified, including 24 Rhodophyta, 7 Chlorophyta, and 4 Phaeophyta (Table 1). A total of 11, 18, 31, and 29 macroalgal taxa were identified, in Jiahe River estuary, Zhifu Island, Fisherman's Wharf and Yangma Island, respectively (Table 1). The highest species numbers were observed in May-June at all sampling sites, except Jiahe River estuary (Table 2). In all 
Table 2 Macroalgal species number in all months at the four sampling sites

\begin{tabular}{ccccccccccccc}
\hline Location & Jan. & Feb. & Mar. & Apr. & May & Jun. & Jul. & Aug. & Sep. & Oct. & Nov. & Dec. \\
\hline A & - & - & 3 & 5 & 3 & 1 & 1 & 1 & 1 & 3 & - & - \\
B & 4 & 3 & 4 & 3 & 4 & 9 & 7 & 7 & 7 & 5 & 4 & 4 \\
C & 8 & 11 & 8 & 6 & 15 & 5 & 11 & 14 & 13 & 10 & 11 & 12 \\
D & 4 & 3 & 3 & 5 & 7 & 14 & 11 & 9 & 12 & 10 & 4 & 4 \\
Total & 9 & 12 & 12 & 12 & 25 & 24 & 19 & 20 & 19 & 15 & 13 & 13 \\
\hline
\end{tabular}

$\mathrm{ABCD}$ refer to the same location as in Table 1.

Table 3 Shannon-Wiener index $\left(H^{\prime}\right)$ of all sampling stations

\begin{tabular}{|c|c|c|c|c|c|c|c|c|c|c|c|c|}
\hline Location & Jan. & Feb. & Mar. & Apr. & May & Jun. & Jul. & Aug. & Sep. & Oct. & Nov. & Dec. \\
\hline A & - & - & 0.31 & 1.62 & 0.87 & $0^{*}$ & $0^{*}$ & $0^{*}$ & $0^{*}$ & 1.26 & - & - \\
\hline B & 1.18 & 0.89 & $0.72 *$ & 1.54 & 1.77 & 1.92 & 1.46 & 1.50 & 1.96 & 1.99 & 1.48 & 1.49 \\
\hline $\mathrm{C}$ & 1.42 & 1.59 & 1.17 & 2.12 & 2.58 & 0.53 & $0.15^{*}$ & 0.24 & 1.41 & 1.64 & 2.69 & 2.75 \\
\hline $\mathrm{D}$ & 1.67 & 0.46 & $0.12 *$ & 2.07 & 1.03 & 1.35 & 1.97 & 1.63 & 3.05 & 2.14 & 1.59 & 1.89 \\
\hline
\end{tabular}

$\mathrm{ABCD}$ refer to the same location as in Table $1 ; * H^{\prime}$ is the lowest in all months in each station.

Table 4 Pianka's niche overlap index $\left(O_{i j}, O_{j i}\right)$ of all sampling sites

\begin{tabular}{|c|c|c|c|c|c|}
\hline \multirow{2}{*}{ Location } & \multirow{2}{*}{$\begin{array}{c}\text { Total species } \\
\text { couple } \\
\text { number }\end{array}$} & \multicolumn{2}{|r|}{$O_{i j}=O_{j i}=0$} & \multicolumn{2}{|r|}{$O_{i j}=O_{j i}>0.9$} \\
\hline & & Species couple number & Percent in total species couple number & Species couple number & Percent in total species couple number \\
\hline A & 19 & 10 & 52.63 & 3 & 15.79 \\
\hline B & 142 & 27 & 19.01 & 33 & 23.24 \\
\hline $\mathrm{C}$ & 713 & 279 & 39.13 & 47 & 6.59 \\
\hline $\mathrm{D}$ & 357 & 86 & 24.09 & 69 & 19.33 \\
\hline
\end{tabular}

$\mathrm{ABCD}$ refer to the same location as in Table 1.

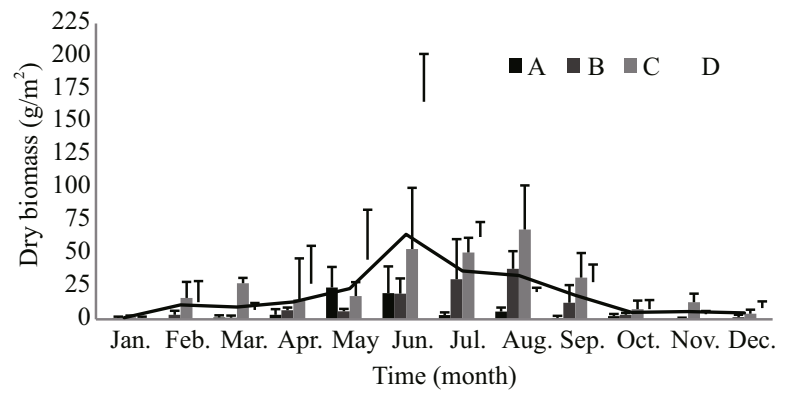

Fig.5 Dry biomass of macroalgae at each site in the Yantai coast annual survey

A. Jiahe River estuary; B. Zhifu Island; C. Fisherman's Wharf; D. Yangma Island.

months, the highest species number was recorded in Fisherman's Wharf and Yangma Island (Table 2).

The Shannon-Wiener index assessments are shown in Table 3. At each sampling site, the lowest value was recorded in spring and summer. In the Jiahe River estuary and Fisherman's Wharf, the index was lower in summer than all other seasons (Table 3).
Pianka's niche overlap index assessments are shown in Table 4. At Zhifu Island, percentage of more than 0.9 of Pianka's niche overlap index in total species couple number $(23.24 \%)$ was higher than that at other sampling sites, and percentage of 0 of Pianka's niche overlap index in total species couple number $(19.01 \%)$ was lower than that at other sampling sites (Table 4), which indicated niche overlap between macroalgael species was higher at Zhifu Island than that at other sampling sites.

\subsubsection{Macroalgal biomass}

Monthly dry biomass measurements are shown in Fig.5. Dry biomass was not significantly different across months in the Jiahe River estuary $(F=1.752$, $P=0.167)$ and at Zhifu Island $(F=2.172, P=0.054)$. In contrast, dry biomass was significantly different across months in Fisherman's Wharf $(F=8.448$, $P=0.000)$ and at Yangma Island $(F=8.058, P=0.000)$. Overall, dry biomass increased from January to June and then declined. The highest dry biomass 

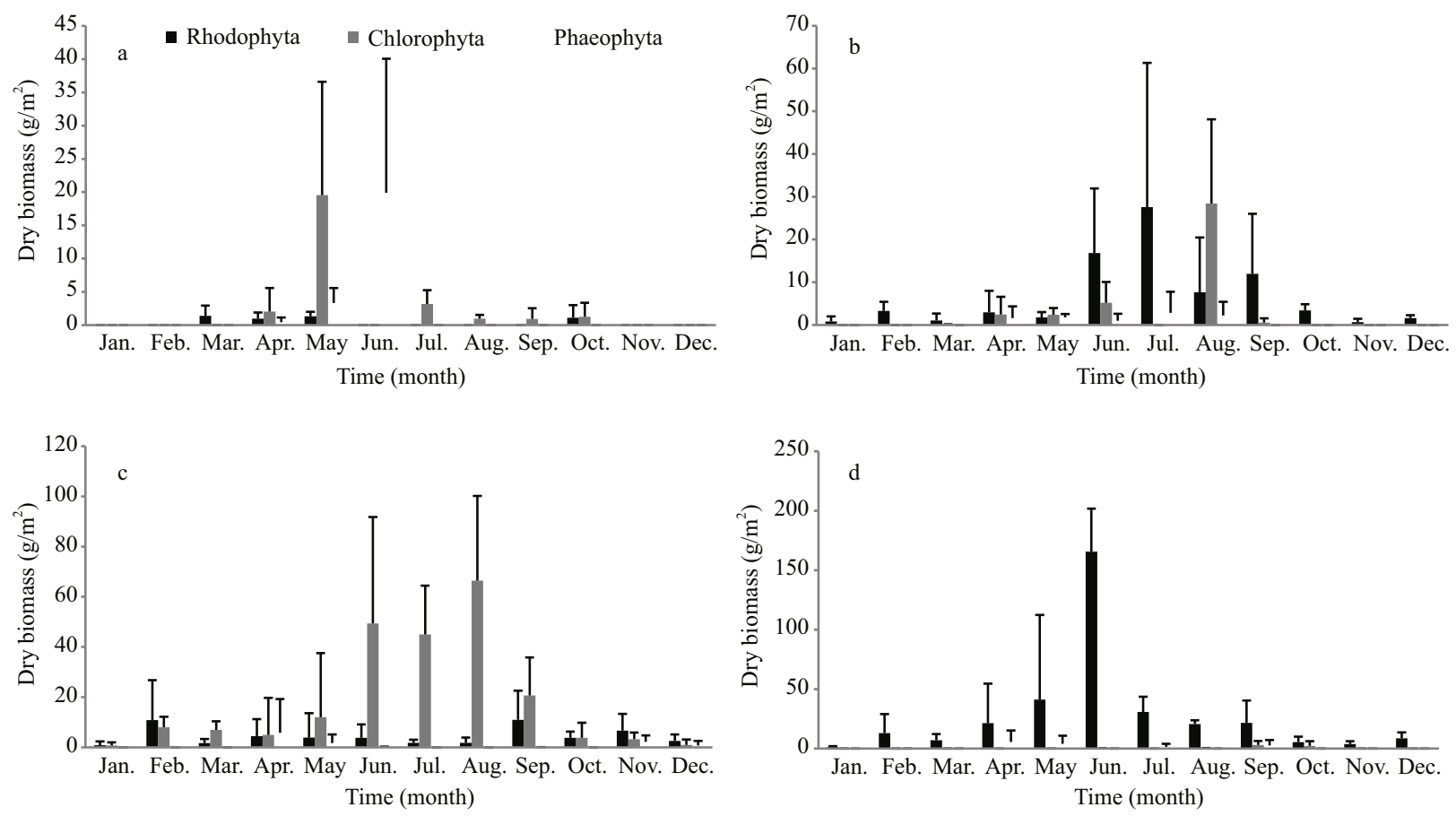

Fig.6 Dry biomass of macroalgae phylum at each site in the Yantai coast annual survey a. Jiahe River estuary; b. Zhifu Island; c. Fisherman's Wharf; d. Yangma Island.

$\left(64.55 \pm 69.12 \mathrm{~g} / \mathrm{m}^{2}\right)$ on the Yantai coast was observed in June (Fig.5), except in the Jiahe River estuary. The highest dry biomass was found at sites in Fisherman's Wharf and at Yangma Island (Fig.5), in all months except May and August.

Green algae biomass was the greatest in the Jiahe River estuary, in April, May, July-October (Fig.6a). In contrast, red algae biomass was the greatest at Zhifu Island, in all months except May and August (Fig.6b). Green algae biomass was the greatest in Fisherman's Wharf in March and May-September (Fig.6c). Annually, red algae biomass was the greatest in Yangma Island (Fig.6d). Brown algae was identified at all sampling sites in April-May (Fig.6).

\subsubsection{Dominant macroalgal taxa}

The dominant species recorded per study site per month are shown in Table 5. Ulva pertusa was the dominant species in Fisherman's Wharf all the year, and in July and October in the Jiahe River estuary, in June and August at Zhifu Island, and in September at Yangma Island. In Fisherman's Wharf, U. pertusa accounted for a greater percentage of total dry biomass than other common species in all months except December (Table 5). In Yangma Island, red algae had the greatest percentage of dry biomass compared with other common species (Table 5). Scytosiphon sp., a brown algae species, was the dominant species in the
Jiahe River estuary in April-May, and at Zhifu Island and Yangma Island in April-May and in Fisherman's Wharf in April (Table 5).

3.2.4 Relationship between macroalgae and environmental variables

In the Jiahe River estuary, the dry biomass of macroalgae was not significantly related to the measured environmental variables $(P>0.05)$ (Table 6 ). In contrast, macroalgal biomass was significantly related to seawater temperature $(P<0.05)$ at Zhifu Island and Fisherman's Wharf (Table 6). At Yangma Island, dry biomass was significantly negatively related to SRP $(P<0.05)$ (Table 6). According to multivariate analysis, no single environmental variable significantly affected the dry biomass of macroalgae in the Jiahe River estuary. Temperature was the most important environmental variable at Zhifu Island $(P=0.009)$ and Fisherman's Wharf $(P=0.039)$. SRP was the most important environmental variable at Yangma Island $(P=0.026)$.

\section{DISCUSSION}

Temperature is considered an important environmental factor determining macroalgal distributions (Santos, 1993). Our study, along with previous studies (Pihl et al., 1996; Plus et al., 2005; 
Table 5 Dominant species of macroalgae in all sampling sites and its percentage in the total dry biomass (\%)

\begin{tabular}{|c|c|c|c|c|c|c|c|c|c|c|c|c|c|c|}
\hline & Phylum & Species & Jan. & Feb. & Mar. & Apr. & May & Jun. & Jul. & Aug. & Sep. & Oct. & Nov. & Dec. \\
\hline \multirow[t]{10}{*}{ A } & Rhodophyta & Ahnfeltia furcellata Okam. & & & & & & & & & & 6.2 & & \\
\hline & & Ceramium japonicum Okamura & & & & 8 & & & & & & & & \\
\hline & & Gracilaria lemaneiformis (Bory) Weber-van Bosse & & & 95 & & & & & & & & & \\
\hline & & Halymenia sp. & & & & & & & & & & 40.9 & & \\
\hline & & Porphyra haitanensis T.J.Chang et B.F.Zheng & & & & & 5.4 & & & & & & & \\
\hline & & Porphyra tenera Kjellinan (AST67-109) & & & & 1 & & & & & & & - & - \\
\hline & Chlorophyta & Monostroma nitidum Wittrock & & & & 59.9 & 80.8 & & & 100 & 100 & & & \\
\hline & & Ulva pertusa Kjellman & & & & & & & 100 & & & 52.9 & & \\
\hline & Phaeophyta & Laminaria japonica Areschoug & & & & & & 100 & & & & & & \\
\hline & & Scytosiphon sp. & & & & 12 & 13.8 & & & & & & & \\
\hline \multirow[t]{15}{*}{$\mathrm{B}$} & Rhodophyta & Ahnfeltia furcellata Okam. & 28.9 & 26.6 & 3 & & & & & & 8 & 25 & 51.3 & 55.6 \\
\hline & & Chondrus ocellatus Holmes & & & & & & & & & & 13 & & \\
\hline & & Gelidium divaricatu Martens & 66.1 & 72.8 & 90.7 & & & & & 10.5 & 45 & 30.2 & 32.5 & 32.1 \\
\hline & & Gloiopeltis furcata (Post. et Rupr.) J.Agardh & & & & & & & 4.7 & & 6.4 & & & \\
\hline & & Gracilaria $\mathrm{sp}$. & & & & & & & & & 3.4 & & 15.7 & \\
\hline & & Gymnogongrus sp. & & & & & & & 72 & & & & & \\
\hline & & Halymenia sp. & & & & & 30 & 25.9 & 6 & 6.4 & 32 & 31 & & 4.9 \\
\hline & & Plocamium telfairiae (Harv.) Harv. (AST 64-0020) & & & & & & & & & & & & 7.4 \\
\hline & & Porphyra haitanensis T. J. Chang et B. F. Zheng & & & & & & 51.8 & & & & & & \\
\hline & & Porphyra tenera Kjellinan (AST67-109) & & & & 42.3 & & & & & & & & \\
\hline & Chlorophyta & Enteromorpha linza (Linnaeus) J. Agardh & & & 6 & & & & & & & & & \\
\hline & & Monostroma nitidum Wittrock & & & & 34.8 & 39.9 & & & & & & & \\
\hline & & Ulva pertusa Kjellman & & & & & & 12.6 & & 74 & & & & \\
\hline & Phaeophyta & Laminaria japonica Areschoug & & & & & 5.2 & & 9 & 5.7 & & & & \\
\hline & & Scytosiphon sp. & & & & 22.9 & 24.7 & & & & & & & \\
\hline \multirow[t]{11}{*}{$\mathrm{C}$} & Rhodophyta & Ahnfeltia furcellata Okam. & & 12.6 & & & 7 & & & & & & 16.3 & 26.7 \\
\hline & & Chondrus ocellatus Holmes & & & & & & & & & & 38.8 & 19.7 & \\
\hline & & Gelidium amansii (Lamouroux) Lamouroux & & & 7.4 & & & & & & & & & 14.9 \\
\hline & & Gelidium divaricatum Martens & & & & & & & & & 8.9 & 6.3 & 7 & 7 \\
\hline & & Gloiopeltis furcata (Post. et Rupr.) J.Agardh & & & & & & 2.5 & & & & & & \\
\hline & & Grateloupia filicina (Lamouroux) C. Agardh & & & & & 6 & & & & & & & \\
\hline & & Rhodomela sp. & & & & 6.8 & & & & & & & & \\
\hline & & Rhodymenia intricate (Okamura) Okamura & & 36.6 & & & & & & & & & & \\
\hline & Chlorophyta & Ulva pertusa Kjellman & 56.8 & 48 & 80.7 & 38 & 46.7 & 93 & 96 & 97 & 65 & 48 & 21.6 & 21.6 \\
\hline & Phaeophyta & Sargassum thunbergii (Mertens ex Roth) O’Kuntze (AST 82-0363) & 35.3 & & & & 18.2 & & & & & & 19.6 & 17.4 \\
\hline & & Scytosiphon sp. & & & & 34.1 & & & & & & & & \\
\hline \multirow[t]{12}{*}{$\mathrm{D}$} & Rhodophyta & Ahnfeltia furcellata Okam. & & & & & & 2.1 & 2 & & & & & \\
\hline & & Gelidium amansii (Lamouroux) Lamouroux & 27.4 & & & & & & & & & & & 21 \\
\hline & & Gelidium divaricatum Martens & 4.8 & & 3 & & & & & & 5.4 & 29.4 & 13 & 34.6 \\
\hline & & Gloiopeltis furcata (Post. et Rupr.) J.Agardh & & & & 26 & 79.4 & & & & & & & \\
\hline & & Gracilaria lemaneiformis (Bory) Weber-van Bosse & & & & & & 68.9 & & & & & & \\
\hline & & Gracilaria sp. & 18.4 & 7.5 & & & & & 52 & 5 & 34.6 & 25 & 54 & 11.6 \\
\hline & & Grateloupia filicina (Lamouroux) C. Agardh & & & & 9.8 & & 2.9 & 28.3 & 57 & 3.5 & 12.1 & & \\
\hline & & Plocamium telfairiae (Harv.) Harv. (AST 64-0020) & & & & & & & & & 20 & & & \\
\hline & & Rhodomela sp. & 49.4 & 91.5 & 94.1 & 37.9 & 10.1 & 9.7 & 7.4 & 20 & 11.5 & & 26.9 & 32.8 \\
\hline & Chlorophyta & Ulva pertusa Kjellman & & & & & & & & & 10 & & & \\
\hline & Phaeophyta & Sargassum thunbergii (Mertens ex Roth) O’Kuntze (AST 82-0363) & & & & & & & & & 9.4 & & & \\
\hline & & Scytosiphon sp. & & & & 20.6 & 8.8 & & & & & & & \\
\hline
\end{tabular}

$\mathrm{ABCD}$ refer to the same location as in Table 1. 
Table 6 Correlations between dry biomass of macroalgae and environmental factors

\begin{tabular}{ccccccccc}
\hline Location & Temperature $\left({ }^{\circ} \mathrm{C}\right)$ & Salinity & $\mathrm{pH}$ & $\mathrm{NH}_{4}^{+}$ & $\mathrm{NO}_{3}^{-}$ & $\mathrm{DIN}$ & $\mathrm{SRP}$ \\
\hline $\mathrm{A}$ & 0.179 & 0.182 & 0.09 & -0.002 & -0.17 & -0.171 & 0.527 \\
$\mathrm{~B}$ & $0.716^{*}$ & 0.145 & 0.325 & -0.328 & -0.318 & -0.374 & -0.234 \\
$\mathrm{C}$ & $0.751^{*}$ & 0.134 & 0.245 & 0.149 & -0.178 & -0.106 & -0.251 \\
$\mathrm{D}$ & 0.413 & 0.344 & 0.156 & 0.132 & -0.196 & -0.191 & $-0.636^{*}$ \\
\hline
\end{tabular}

$\mathrm{ABCD}$ refer to the same location as in Table 1; * Correlation is significant at the 0.05 level (two-tailed).

Sousa-Dias and Melo, 2008), has shown that macroalgal communities can have higher species richness and biomass in summer than in other seasons (Table 2; Fig.5). In summer, Ulva pertusa was the dominant species along the Yantai coast (Table 3). Similarly, many studies have found that Ulva sp. biomass peaked in spring and summer (Ferreira and Ramos, 1989; Solidoro et al., 1997; Plus et al., 2005). Zhuang and Chen (2003) found similar summer peaks in Moon Bay, near Fisherman's Wharf, on the Yantai coast. If average seawater temperature rises $1-3^{\circ} \mathrm{C}$ in the next 100 years as being predicted (IPCC, 2007), but other environmental factors remain static, the dominance of $U$. pertusa would be expected to increase (Sousa-Dias and Melo, 2008). This could then increase the macroalgae bloom risk and negatively affect the coastal ecosystem (McGlathery, 2001).

Macroalgal community structure can reflect the ecological status of a coastal environment (Guinda et al., 2012). An increased amount of the opportunistic macroalgae Ulva sp. generally indicates a poor to bad ecological status (Arévalo et al., 2007). Thus, the high abundance and frequency of $U$. pertusa along the Yantai coast, especially at Fisherman's Wharf, indicates low water quality in the region.

Brown algae appeared in spring (April-May) at all sampling sites (Fig.6), which may suggest temperature was at the optimal level for brown algae growth at this time $\left(9.70 \pm 2.64^{\circ} \mathrm{C}\right.$ and $16.74 \pm 1.79^{\circ} \mathrm{C}$ ) (Bolton and Lüning, 1982). For example, the brown algae Scytosiphon sp. did not appear during higher temperature seasons, and does not survive in winter in Danish waters (Kristiansen and Pedersen, 1979; Kristiansen et al., 1994). Lüning (1980) found that the highest temperature for survival of Laminaria saccharina spores was $21-22^{\circ} \mathrm{C}$.

Macroalgal growth is controlled by light distribution, owing to its key role in photosynthesis (Lüning, 1990). In our study, the intertidal area of Fisherman's Wharf $(800 \mathrm{~m} \times 365 \mathrm{~m})$ was larger than that at Yangma Island $(80 \mathrm{~m} \times 30 \mathrm{~m})$, and light intensity may thus be lower at the former owing to water depth differences. This could explain the higher richness and biomass red algae in Yangma Island and higher biomass of green algae at Fisherman's Wharf (Table 5; Fig.6), as red and green algae have differing optimal light conditions (King and Schramm, 1976). Although macroalgae are able to tolerate low light conditions (Hellebust, 1970), some red algae have shown lower photosynthetic ability at lower light intensities (King and Schramm, 1976). For example, the relative growth rate of Gracilaria lemaneiformis, a red algae species, increased with increasing daily light density received (Xu and Gao, 2008). In contrast, green algae, especially Ulva sp., can tolerate low light levels, owing to differing photoadaptive strategies for sporulation in response to varying saturating irradiance (Han et al., 2003).

The availability of nitrogen and phosphorus can favor massive proliferation of opportunistic green macroalgae (Villares and Carballeira, 2003), evidenced by the dominance of $U$. pertusa at higher nutrient levels along the Yantai coast in summer (Table 5; Fig.4). Other studies concur with our findings (Díaz et al., 2002; Arévalo et al., 2007), reporting the dominant community at high nutrient levels was normally composed of green algae (Ulvaceae). Ulva sp. has large surface areas and halfsaturation constants for nitrogen (Lobban and Harrison, 1997), and may thus grow better in higher nutrient conditions (Guerry et al., 2009). In our study, the concentration of dissolved inorganic nitrogen was high ( $>4.5 \mu \mathrm{mol} / \mathrm{L}$; Fig. $4 \mathrm{c})$ year round, suggesting that nitrogen availability is not limiting macroalgal growth. Ammonia was $11 \%-68 \%$ of the DIN year round on the Yantai coast, but its concentration was not significantly related to the dry biomass of macroalgae $(P>0.05)$ (Table 6). This suggests that ammonia levels may affect algae growth rates (Fong et al., 1993), but it is not a limiting factor as algae can assimilate nitrogen (Kratz and Myers, 1955; Williams and Carpenter, 1997). In our study, SRP concentrations were low $(<0.29 \mu \mathrm{mol} / \mathrm{L})$ at all sites (Fig.4d). Indeed, 
SRP concentrations were lower than the saturation level for phosphorus uptake in macroalgae (Wallentinus, 1984), indicating that phosphorus limitation may be important on the Yantai coast. This is in agreement with Wang et al. (2012), who demonstrated SRP limitation in 2010 in Sishili Bay, near the Yantai coast.

Nutrient levels can affect the metabolism of nitrogen and carbon in macroalgae (Turpin, 1991). Such effects are species-specific owing to different storage capacity and nutrient requirements for growth (Larned, 1998). The green alga, U. pertusa, was the dominant species in Fisherman's Wharf during the study period, which may be attributable to the high SRP concentration (Table 5; Fig.4d). Indeed, the uptake rates of phosphorus and growth of $U$. pertusa have been shown to increase with higher concentrations of SRP (Nan and Dong, 2004). This may be because some green macroalgae, such as Ulva sp. and Enteromorpha sp., are able to store phosphorus (Björnsäter and Wheeler, 1990). With the lower $(<0.09 \mu \mathrm{mol} / \mathrm{L}) \mathrm{SRP}$ concentration in Yangma Island, red algal species dominated (Table 5; Fig.4b). Kraufvelin et al. (2010) also found more red algal species in low nutrient areas of the rocky coast of SE Norway. Thus, red algae may have a competitive advantage over green algae under low SRP concentration conditions.

Spatial patterns of macroalgae abundance have been related to the complexity of the substratum (Menconi et al., 1999; Zuccarello et al., 2001; Nedwell et al., 2002). In our study, the higher dry biomass and species number of macroalgae at Fisherman's Wharf and Yangma Island than at Jiahe River estuary and Zhifu Island (Table 2; Fig.5) may be due to the different sediment types. Richardson (1979) found that pebbled areas provide more anchorage points for macroalgal growth than rocky areas. In the Jiahe River estuary, there was no macroalgae in the sandy substrate, as sand substrate provides less anchorage for macroalgae (Quartino et al., 2001). In general, the deposition of fine sediment may result in insufficient oxygen and cause higher mortality in macroalgae recruits (Kawamata et al., 2011).

Together with other environmental variables, wave exposure may affect macroalgal distribution (Gaylord et al., 2002; Nishihara and Terada, 2010). On the Yantai coast, the strongest waves are mainly in the northeast direction, and the tidal range is about $152 \mathrm{~cm}$ (Liu et al., 2007). The prevailing winds are northward (Cai, 1978). Owing to their location, the waves at
Jiahe River estuary and Zhifu Island are stronger than those at Fisherman's Wharf and Yangma Island (Fig.2). Waves can induce turbidity and affect the light availability for macroalgae (Campbell et al., 1988; Balata et al., 2007). For example, Wing and Patterson (1993) found that higher wave motion decreased light intensity. Nishihara and Terada (2010) found that Phaeophyta increased in species richness with increasing wave exposure, which may explain the higher percentage of phaeophyta in the Jiahe River estuary and at Zhifu Island in April-June (Table 5).

\section{CONCLUSION}

Abiotic factors may significantly influence macroalgal assemblages. Our results agree with previous studies that macroalgae is an excellent environmental indicator, owing to the relationship between macroalgal communities and environmental variables, such as seawater temperature and nutrient levels. Our study demonstrated that natural conditions and human activities affect the macroalgal community on the Yantai coast, which has rarely been demonstrated using field data of macroalgal abundance and environment variables. Further study is required of the physiological mechanisms determining how environment variables affect macroalgae along the Yantai coast.

\section{References}

Arévalo R A, Pinedo S, Ballestero E. 2007. Changes in the composition and structure of Mediterranean rocky-shore communities following a gradient of nutrient enrichment: descriptive study and test of proposed methods to assess water quality regarding macroalgae. Mar. Pollut. Bull., 55: 104-113.

Arnold K E, Murray S N. 1980. Relationships between irradiance and photosynthesis for marine benthic green macroalgae (Chlorophyta) of differing morphologies. $J$. Exp. Mar. Biol. Ecol., 43: 183-192.

Balata D, Piazzi L, Cinelli F. 2007. Increase of sedimentation in a subtidal system: effects on the structure and diversity of macroalgal assemblages. J. Exp. Mar. Biol. Ecol., 351: 73-82.

Bermejo R, Vergara J J, Hernández I. 2012. Application and reassessment of the reduced species list index for macroalgae to assess the ecological status under the Water Framework Directive in the Atlantic coast of Southern Spain. Ecol. Indic., 12: 46-57.

Björnsäter B R, Wheeler P A. 1990. Effect of nitrogen and phosphorus supply on growth and tissue composition of Ulva fenestrate and Enteromorpha intestinalis (Ulvales, Chlorophyta). J. Phycol., 26: 603-611. 
Bolton J J, Lüning K. 1982. Optimal growth and maximal survival temperatures of Atlantic Laminaria species (Phaeophyta) in culture. Mar. Biol., 66: 89-94.

Burkholder J M, Tomasko D A, Touchette B W. 2007. Seagrasses and eutrophication. J. Exp. Mar. Biol. Ecol., 350: 46-72.

Cai A Z. 1978. On the formation of Zhifu tombolo. Ogean. Limnol. Sin., 9: 1-14. (in Chinese with English abstract)

Campbell E E, du Preez D R, Bate G C. 1988. The light environment in a high energy surf-zone with high phytoplankton biomass. Bot. Mar., 31: 329-335.

Correll D L. 1978. Estuarine productivity. Bioscience, 28: 646650.

D'Antonio C M. 1986. Role of sand in the domination of hard substrata by the intertidal alga Rhodomela larix. Mar. Ecol. Prog. Ser., 27: 263-275.

Diaz J R, Rosenberg R. 1995. Marine benthic hypoxia: a review of its ecological effects and the behavioural responses of benthic macrofauna. Oceanogr. Mar. Biol., 33: 245-303.

Díaz P, López J J, Piriz M L. 2002. Symptoms of eutrophication in intertidal macroalgal assemblages of Nuevo Gulf (Patagonia, Argentina). Bot. Mar., 45: 267-273.

Díez I, Secilla A, Santolaria A, Gorostiaga J M. 1999. Phytobenhic intertidal community structure along an environmental pollution gradient. Mar. Pollut. Bull., 38: 463-472.

Ferreira J G, Ramos L. 1989. A model for the estimation of annual production rates of macrophyte algae. Aquat. Bot., 33: 53-70.

Fitzgerald W J Jr. 1978. Environmental parameters influencing the growth of Enteromorpha clathrata (Roth) J. Ag. in the intertidal zone on Guam. Bot. Mar., 21: 207-220.

Flindt M R, Pardal M A, Lillebø A I, Martins I, Marques J C. 1999. Nutrient cycling and plant dynamics in estuaries: a brief review. Acta. Oecol., 20: 237-248.

Fong P, Zedler J B, Donohoe R M. 1993. Nitrogen vs. phosphorus limitation of algal biomass in shallow coastal lagoons. Limnol. Oceanogr., 38(5): 906-923.

Gaylord B, Reed D C, Raimondi P T, Washburn L, McLean S R. 2002. A physically based model of macroalgal spore dispersal in the wave and current-dominated nearshore. Ecology, 83: 1 239-1 251.

Gordon E M, Birch P B, Mccomb A J. 1980. The effect of light, temperature, and salinity on photosynthetic rates of an estuarine Cladophora. Bot. Mar., 23: 749-755.

Gordon L I, Jennings J C, Ross Jr A A, Krest J M. 1993. A Suggested Protocol for Continuous Flow Automated Analysis of Seawater Nutrients (Phosphate, Nitrate, Nitrite and Silicic Acid) in the WOCE Hydrographic Program and the Joint Global Ocean Fluxes Study. WOCE Hydrographic Program Office, Methods Manual WHPO. No.68/91. p.1-52.

Guerry A D, Menge B A, Dunmore R A. 2009. Effects of consumers and enrichment on abundance and diversity of benthic algae in a rocky intertidal community. J. Exp. Mar. Biol. Ecol., 369: 155-164.
Guinda X, Juanes J A, Puente A, Echavarri-Erasun B. 2012. Spatial distribution pattern analysis of subtidal macroalgae assemblages by a non-destructive rapid assessment method. J. Sea Res., 67: 34-43.

Han T J, Han Y S, Kim K Y, Kim J H, Shin H W, Kain J M, Callow J A, Callow M E. 2003. Influences of light and UV-B on growth and sporulation of the green alga Ulva pertusa Kjellman. J. Exp. Mar. Biol. Ecol., 290: 115-131.

Hellebust J A. 1970. Marine Ecology. Environmental Factors. Wiley-Interscience, London. p.125-158.

Hong N, Lin A H, Hou J. 2003. SPSS for Windows. Tsinghua University Press, Beijing. (in Chinese)

IPCC (Intergovernmental Panel on Climate Change). 2007. Climate Change 2007: Synthesis Report. Cambridge University Press, Cambridge, UK.

Kawamata S, Yoshimitsu S, Tanka T, Igari T, Tokunaga S. 2011. Importance of sedimentation for survival of canopyforming fucoid algae in urchin barrens. J. Sea Res., 66: 76-86.

King R J, Schramm W. 1976. Photosynthetic rates of benthic marine algae in relation to light and seasonal variations. Mar. Biol., 37: 215-222.

Kinney E H, Roman C T. 1998. Response of primary producers to nutrient enrichment in a shallow estuary. Mar. Ecol. Prog. Ser., 163: 89-98.

Kratz W A, Myers J. 1955. Nutrition and growth of several blue-green algae. Am. J. Bot., 42: 282-287.

Kraufvelin P, Lindholm A, Pedersen M F, Kirkerud L A, Bonsdorff E. 2010. Biomass, diversity and production of rocky shore macroalgae at two nutrient enrichment and wave action levels. Mar. Biol., 157: 29-47.

Kristiansen A A, Pedersen P M, Moseholm L. 1994. Salinitytemperature effects on growth and reproduction of Scytosiphon lomentaria (Fucophyceae) along the salinity gradient in Danish waters. Phycol., 22: 444-454.

Kristiansen A A, Pedersen P M. 1979. Studies on life history and seasonal variation of Scytosiphon lomentaria (Fucophyceae, Scytosiphonales) in Denmark. Bot. Tidss., 74: 31-56.

Lapointe B E, Bedford B J. 2007. Drift rhodophyte blooms emerge in Lee County, Florida, USA: Evidence of escalating coastal eutrophication. Harmful Algae, 6: 421437.

Larned S T. 1998. Nitrogen-versus phosphorus-limited growth and sources of nutrients for coral reef macroalgae. Mar. Biol., 132: 409-421.

Liu C N, Jin B F, Song J, Wang H W, Zhang L, Wang X M. 2007. Study on the sediment transport direction on the beach of Taozi Bay, Yantai. Mar. Sci., 31: 59-63. (in Chinese with English abstract)

Liu Y H, Liu X J, Xing H Y, Jin Y, Ma Y Q, Liu X B. 2006. Analysis of the water quality in the sea area of Sishili Bay of Yantai in 2003. Trans. Oceanogr. Limnol., 3: 93-97. (in Chinese with English abstract)

Lobban C S, Harrison P J. 1997. Seaweed Ecology and Physiology. Cambridge University Press, Cambridge.

Lüning K. 1980. Critical levels of light and temperature 
regulating the gametogenesis of three Laminaria species. J. Phycol., 16: 1-15.

Lüning K. 1990. Seaweeds: Their Environment, Biogeography and Ecophysiology. Wiley Interscience, New York.

Masson P, Greig S P. 1983. Quantitative Plant Ecology. Blackwell Science Publication, London. p.105-128.

McGlathery K J. 2001. Macroalgal blooms contribute to the decline of seagrass in nutrient-enriched coastal Waters. $J$. Phycol., 37: 453-456.

Melville F. 2005. Mangrove Algae in the Assessment of Estuarine Pollution. Ph.D. dissertation. University of Technology, Sydney. p.289.

Menconi M, Benedetti-cecchi L, Cinelli F. 1999. Spatial and temporal variability in the distribution of algae and invertebrates on rocky shores in the northwest Mediterranean. J. Exp. Mar. Biol. Ecol., 233: 1-23.

Nan C R, Dong S L. 2004. Comparative studies on phosphorus uptake and growth kinetics of microalga Tetraselmis subcordiformis and the macroalga Ulva pertusa. J. Ocean. Univ. China, 3: 56-59. (in Chinese with English abstract)

Nedwell D B, Sage A S, Underwood G J C. 2002. Rapid assessment of macroalgal cover on intertidal sediments in a nitrified estuary. Sci., Total Environ., 285: 97-105.

Niggl W, Haas A F, Wild C. 2010. Benthic community composition affects $\mathrm{O}_{2}$ availability and variability in a Norghern Red Sea Fringing reef. Hydrobio., 644: 401405.

Nishihara G N, Terada R. 2010. Species richness of marine macrophytes is correlated to a wave exposure gradient. Phycol. Res., 58: 280-292.

Peckol P, Rivers J S. 1995. Physiological responses of the opportunistic macroalgae Cladophora vagabunda (L.) van den Hoek and Gracilaria tikvahiae (McLachlan) to environmental disturbances associated with eutrophication. J. Exp. Mar. Biol. Ecol., 190: 1-16.

Pihl L, Magnusson G, Isaksson I, Wallentinus I. 1996. Distribution and growth dynamics of ephemeral macroalgae in shallow bays on the Swedish west coast. $J$. Sea Res., 35: 169-180.

Plus M, Auby I, Verlaque M, Levavasseur G. 2005. Seasonal variations in photosynthetic irradiance response curves of macrophytes from Mediterranean coastal lagoon. Aquat. Bot., 81: 157-173.

Pregnall A M, Rudy P P. 1985. Contribution of green macoalgal mats (Enteromorpha spp.) to seasonal production in an estuary. Mar. Ecol. Prog. Ser., 24: 167-176.

Quartino M L, Schloss H K I R, Wiencke C. 2001. Biomass and associations of benthic marine macroalgae from the inner Potter Cove (King George Island, Antarctica) related to depth and substrate. Polar Biol., 24: 349-355.

Richardson M G. 1979. The distribution of Antarctic marine macro-algae related to depth and substrate. Br. Antarct. Sury. Bull., 49: 1-13.

Santos R. 1993. A multivariate study of biotic and abiotic relationships in a subtidal algal stand. Mar. Ecol. Prog. Ser., 94: 181-190.

Shannon C E, Weaver W. 1949. The Mathematical Theory of Communication. University of Illinois Press, Urbana.

Shellem B H, Josselyn M N. 1982. Physiological ecology of Enteromorpha clathrata (Roth) Grev. on a salt marsh mudflat. Bot. Mar., 25: 541-549.

Solidoro C, Brando V E, Dejak C, Franco D, Pastres R, Pecenik G. 1997. Long term simulations of population dynamics of Ulva in the lagoon of Venice. Ecol. Model., 102: 259272.

Sousa-Dias A, Melo R A. 2008. Long-term abundance patterns of macroalgae in relation to environmental variables in the Tagus Estuary (Portugal). Estuar. Coast. Shelf Sci., 76: $21-28$.

Turpin D H. 1991. Effects of inorganic N availability on algal photosynthesis and carbon metabolism. J. Phycol., 27: 14-20.

Villares R, Carballeira A. 2003. Seasonal variation in the concentrations of nutrients in two green macroalgae and nutrient levels in sediments in the Rías Baixas (NW Spain). Estuar. Coast. Shelf Sci., 58: 887-900.

Wallentinus I. 1984. Comparisons of nutrient uptake rates for Baltic macroalgae with different thallus morphologies. Mar. Biol., 80: 215-225.

Wang Y J, Liu D Y, Dong Z J, Di B P, Shen X H. 2012. Temporal and spatial distributions of nutrients under the influence of human activities in Sishili Bay, northern Yellow Sea of China. Mar. Pollut. Bull., 64: 2 708-2 719.

Williams S L, Carpenter R C. 1997. Grazing effects on nitrogen fixation in coral reef algal turfs. Mar. Biol., 130: 223-231.

Wing S R, Patterson M R. 1993. Effects of wave-induced lightflecks in the intertidal zone on photosynthesis in the macroalgae Postelsia palmaeformis and Hedophyllum sessile Phaeophyceae). Mar. Biol., 116: 519-525.

Xu J T, Gao K S. 2008. Growth, pigments, UV-absorbing compounds and agar yield of the economic red seaweed Gracilaria lemaneiformis (Rhodophyta) grown at different depths in the coastal waters of the South China Sea. J. Appl. Phycol., 20: 681-686.

Zeng C K. 2008. Seaweeds in Yellow Sea and Bohai Sea of China. Science Press, Beijing. (in Chinese)

Zhuang S H, Chen L X, Wang K M. 2001. The spatial distribution pattern of benthic rhodophyta in Yantai lithofacies intertidal zones of Yellow Sea. J. Yantai. Univ., 14(4): 255-263. (in Chinese with English abstract)

Zhuang S, Chen L. 2003. Seasonal fluctuation of benthic algal community in the rock intertidals of Moon Bay, Yantai. $J$. Ocean Univ. Qingdao, 33: 719-726. (in Chinese with English abstract)

Zuccarello G C, Yeates P H, Wright J T, Bartlett J. 2001. Population structure and physiological differentiation of haplotypes of Caloglossa leprieurii (Rhodophyta) in a mangrove intertidal zone. J. Phycol., 37: 235-244. 